\title{
Filamentous Fungi Transported by Birds During Migration Across the Mediterranean Sea
}

\author{
Antonio Alfonzo $\cdot$ Nicola Francesca $\cdot$ \\ Ciro Sannino • Luca Settanni · Giancarlo Moschetti
}

Received: 6 July 2012/ Accepted: 15 October 2012/Published online: 11 November 2012

(c) Springer Science+Business Media New York 2012

\begin{abstract}
The potential for the transport and diffusion of some pathogenic microorganisms by migratory birds is of concern. Migratory birds may be involved in the dispersal of microorganisms and may play a role of mechanical and biological vectors. The efficiency of dispersal of pathogenic microorganisms depends on a wide range of biotic and abiotic factors that influence the survival or disappearance of a given agent in a geographical area. In the present study, 349 migratory birds were captured in four sites (Mazara del Vallo, Lampedusa, Ustica and Linosa), representing the main stop-over points during spring and autumnal migration, and analyzed for the presence of filamentous fungi. A total of 2,337 filamentous fungi were isolated from 216 birds and identified by a combined phenotypic-genotypic approach to species level. Twelve species were identified in the study, with Cladosporium cladosporioides, Alternaria alternata, and Aspergillus niger as the most abundant. The transport of these fungal species isolated in this study is of considerable importance because some of these species can create dangers to human health.
\end{abstract}

\section{Introduction}

The migration of birds depends on the seasonality of food resources; it takes place in autumn and spring with a round trip to the resting areas and a return to the territories of nesting, respectively $[18,19]$. The islands of the Mediterranean Sea represent important resting sites (stop-over),

A. Alfonzo · N. Francesca - C. Sannino - L. Settanni ·

G. Moschetti $(\square)$

DEMETRA Department, Università degli Studi di Palermo,

Viale delle Scienze 4, 90128 Palermo, Italy

e-mail: giancarlo.moschetti@unipa.it where birds increase the fat lost during their flights between North Africa and Europe and vice versa [10]. The monitoring of bird movements is important not only to investigate on the demography of the different species [3], but also to evaluate the microbial populations transported by birds [7].

The recent studies carried out on the microbial populations transported by birds have been mainly related to safety aspects [24, 27], since birds contribute to disseminate various microorganisms in the environment [22]. Birds may play a defining role in long distance movement of microorganisms; for example, in the case of yeasts, it has been shown that insects may transport cells within approximately $10 \mathrm{~km}$ [9], while migratory birds are effective at longer distances [7]. So far, a few studies analyzed filamentous fungi associated with migratory birds $[4,14]$, while bacteria and yeasts have been better investigated $[4,6,7]$. Thus, on the above considerations, the main objective of the present study was to analyze the filamentous fungi carried by birds at the moment of landing at their stop-over during spring (at Lampedusa and Ustica) and winter (at Linosa and Mazara del Vallo) migration in the Mediterranean.

\section{Materials and Methods}

Sampling Sites and Analysis of Birds

Migrating birds were monitored during their movements within the "Progetto Piccole Isole" of the Sicily region (southern Italy). Birds to be ringed were caught in four experimental sites located within Sicily region: (1) Lampedusa island $\left(35^{\circ} 51^{\prime} \mathrm{N} 12^{\circ} 58^{\prime} \mathrm{E}\right.$; 25 th-27th April 2009); (2) Ustica island $\left(38^{\circ} 7^{\prime} \mathrm{N} 13^{\circ} 18^{\prime} \mathrm{E}\right.$; 2 nd-4th May 2009); (3) Linosa island $\left(35^{\circ} 86^{\prime} \mathrm{N} 12^{\circ} 86^{\prime} \mathrm{E} ; 27\right.$ th -29 th 
September 2009); (4) Riserva Naturale Integrale Lago Preola and Gorghi Tondi (Mazara del Vallo, TP; $37^{\circ} 39^{\prime} \mathrm{N}$ $12^{\circ} 35^{\prime}$ E; 4th-6th September 2009). Sites 1-3 are small islands surrounding Sicily (Fig. 1). All sites represent important stop-over points for migrating birds [25]. The birds were captured and identified as previously reported by Francesca et al. [7]. The analysis included the measurement of subcutaneous fat amount (SFA) of the abdominal region [15] that was evaluated by visual biometric measurement. The main energy source during flight is the body fat. The birds with low fat reserves ( 0 or 1$)$ have the necessity of stopping in some resting sites (stop-over) along the route. Birds were released in the same areas of capturing soon after analysis.

Isolation and Identification of Filamentous Fungi

In order to evaluate the contribution of birds to filamentous fungi dissemination through feces, only cloacae of birds were analyzed $[4,7]$. Cloacae were plugged with sterile cotton swabs and streaked onto malt extract agar (MEA) (Oxoid, Milan, Italy) supplemented with streptomycin sulfate $(0.05 \mathrm{~g} / \mathrm{l})$ (Sigma-Aldrich, Milan, Italy). Petri dishes were incubated at ambient temperature during transport and, once in laboratory, at $25 \pm 1{ }^{\circ} \mathrm{C}$ for 3 weeks; Petri dishes were observed at 24-h intervals and each fungal colony ( $\varnothing$ about $2 \mathrm{~mm}$ ) was immediately transferred to a new Petri dish containing the same agar substrate. All samples were analyzed in duplicate.

All fungal colonies were picked up from agar plates and purified to homogeneity after several sub-culturing steps onto MEA. The isolates were first differentiated by morphological characterization including color, texture, diffusible pigments, exudates, growth zones, aerial, and submerged hyphae, growth rate, and topography. All colonies were subjected to microscopic analysis $[2,5]$ through a light microscope (Carl Zeiss Ltd). Subsequently, up to 10 isolates or less for the less numerous morphological groups were subjected to genetic analysis. Genomic DNA was extracted from single-spore cultures following a standard cetyl-trimethyl-ammonium-bromide-based protocol [23]. Filamentous fungi were analyzed by restriction fragment length polymorphism of the region spanning the internal transcribed spacers (ITS1 and ITS2) and the 5.8S rRNA gene. The DNA fragments were amplified with the primer pair ITS1F [8] and ITS4 [29] by means of T1 Thermocycler (Biometra, Göttingen, Germany). The amplicons were then digested with the endonucleases $C f o \mathrm{I}$ and HaeIII (MBI Fermentas, St. Leon-Rot, Germany) at $37{ }^{\circ} \mathrm{C}$ for $8 \mathrm{~h}$. ITS products, as well as restriction fragments were analyzed on agarose gels using $2 \%(\mathrm{w} / \mathrm{v})$ agarose in $1 \times$ TBE $(89 \mathrm{mM}$ Tris-borate, 2 mM EDTA pH 8) buffer. Gels were stained with SYBR safe DNA gel stain (Invitrogen, Milan, Italy), visualized by UV transillumination and recorded with Gel Doc 1000 Video Gel Documentation System (BioRad, Richmond, USA). GeneRuler 100 bp (Fermentas, Milan, Italy)—standard DNA ladders were used as molecular markers. One isolate per group was processed by sequencing of the 5.8S-ITS rRNA region to confirm the morphological identification. PCR product of 5.8S-ITS rRNA region was amplified and visualized as above. DNA cycle sequencing reactions were performed at Primm-Biotech (Milan, Italy). The identities of the sequences were determined by BlastN [1] search against the NCBI non-redundant sequence database located at http://www.ncbi.nlm.nih.gov.

\section{Statistical Analysis}

Data obtained by evaluation of bird SFA were subjected to statistical analysis by Chi-square test. All the analyses were conducted in PSPP v.0.7.8 (Copyright (C) 2007 Free Software Foundation, Inc.).

Fig. 1 Sites of bird ringing

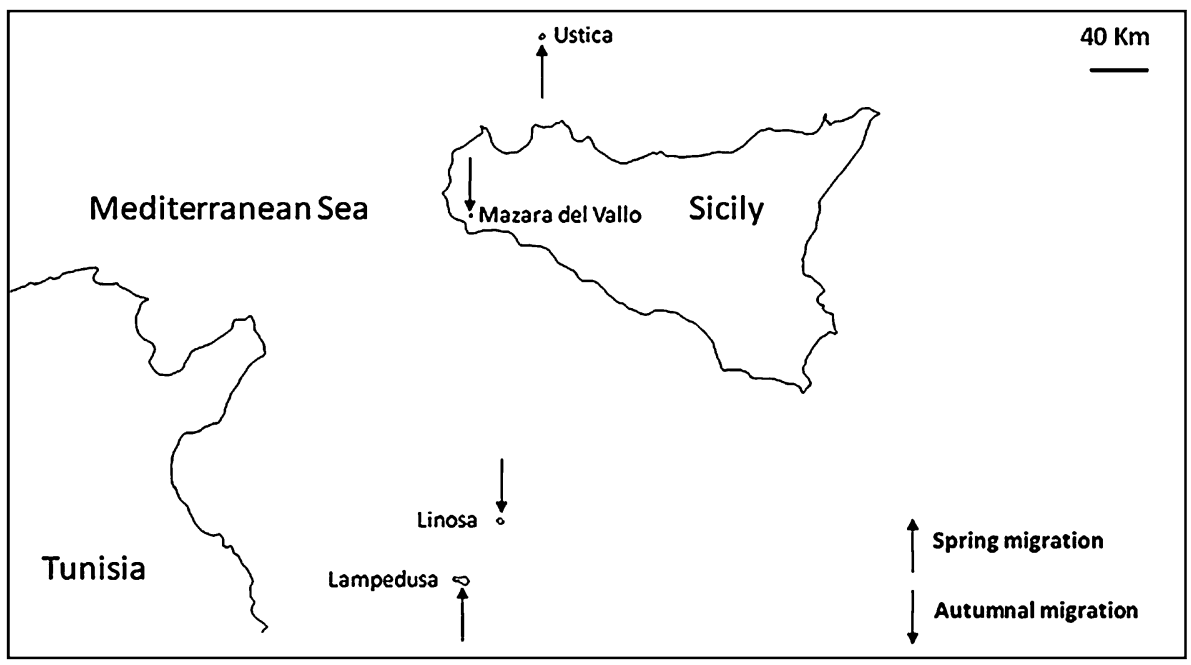




\section{Results}

\section{Isolation of Filamentous Fungi}

The identification of the 349 birds captured was previously showed by Francesca et al. [7]. Two hundred and sixteen individuals, representing $61.89 \%$ of the birds analyzed, were positive for filamentous fungi isolation (Table 1). The bird families showing the highest frequencies of filamentous fungi were Sylviidae (145 individuals), Muscicapidae (37), and Turdidae (25). A total of 2,337 filamentous fungal isolates were collected from bird cloacae and stored in glycerol stocks at $-20{ }^{\circ} \mathrm{C}$ until further determination.

\section{Grouping and Identification of Fungi}

After microscopic inspection and morphological differentiation, the isolates were divided into 12 groups (Table 2).

Table 1 Bird captured in four Sicilian ringing sites

\begin{tabular}{|c|c|c|c|c|}
\hline Bird family & Bird species & $\begin{array}{l}\text { No. of } \\
\text { birds }\end{array}$ & $\begin{array}{l}\text { No. of birds carrying } \\
\text { fungi }\end{array}$ & $\begin{array}{l}\text { Sampling sites (number of } \\
\text { birds) }\end{array}$ \\
\hline Fringillidae & Carduelis cannabina, Linnaeus 1758 (linnet) & 2 & 0 & \\
\hline Hirundinidae & Hirundo rustica, Linnaeus 1758 (swallow) & 12 & 2 & $\operatorname{Ln}(1) ; \mathrm{U}(1)$ \\
\hline Laniidae & Lanius senator, Linnaeus 1758 (woodchat shrike) & 2 & 1 & $\mathrm{~L}(1)$ \\
\hline Motacillidae & Anthus trivialis, Linnaeus 1758 (tree pipit) & 2 & 2 & $\mathrm{~L}(1) ; \mathrm{U}(1)$ \\
\hline \multirow[t]{3}{*}{ Muscicapidae } & $\begin{array}{l}\text { Ficedula albicollis, Temminck } 1815 \text { (collared } \\
\text { flycatcher) }\end{array}$ & 1 & 1 & $\mathrm{U}(1)$ \\
\hline & F. hypoleuca, Pallas 1764 (pied flycatcher) & 6 & 3 & $\mathrm{U}(3)$ \\
\hline & Muscicapa striata, Pallas 1764 (spotted flycatcher) & 51 & 33 & $\mathrm{~L}(2) ; \mathrm{U}(31)$ \\
\hline Oriolidae & Oriolus oriolus, Linnaeus 1758 (golden oriole) & 3 & 0 & \\
\hline Paridae & Parus major, Linnaeus 1758 (great tit) & 2 & 2 & $\operatorname{MdV}(2)$ \\
\hline \multirow[t]{2}{*}{ Passeridae } & $\begin{array}{l}\text { Passer hispaniolensis, Temminck } 1820 \text { (Spanish } \\
\text { sparrow) }\end{array}$ & 8 & 2 & $\operatorname{MdV}(2)$ \\
\hline & P. montanus, Linnaeus 1758 (tree sparrow) & 1 & 0 & \\
\hline \multirow[t]{15}{*}{ Sylviidae } & $\begin{array}{l}\text { Acrocephalus arundinaceus, Linnaeus } 1758 \text { (great- } \\
\text { reed warbler) }\end{array}$ & 3 & 0 & \\
\hline & A. schoenobaenus, Linnaeus 1758 (sedge warbler) & 6 & 3 & $\mathrm{~L}(1) ; \mathrm{U}(2)$ \\
\hline & $\begin{array}{l}\text { Acrocephalus scirpaceus, Hermann } 1804 \text { (reed } \\
\text { warbler) }\end{array}$ & 12 & 6 & $\operatorname{MdV}(4) ; \mathrm{U}(2)$ \\
\hline & Cettia cetti, Temminck 1820 (cetti’s warbler) & 2 & 2 & $\operatorname{MdV}(2)$ \\
\hline & Hippolais icterina, Vieillot 1817 (icterine warbler) & 24 & 15 & L (4); U (11) \\
\hline & H. polyglotta, Vieillot 1817 (melodious warbler) & 1 & 1 & $\mathrm{U}(1)$ \\
\hline & Phylloscopus collybita, Vieillot 1817 (chiffchaff) & 1 & 1 & $\mathrm{~L}(1)$ \\
\hline & P. sibilatrix, Bechstein 1793 (wood warbler) & 5 & 4 & $\mathrm{U}(4)$ \\
\hline & P. trochilus, Linnaeus 1758 (willow warbler) & 7 & 3 & L (2); Ln (1) \\
\hline & Sylvia atricapilla, Linnaeus 1758 (blackcap) & 2 & 0 & \\
\hline & S. borin, Boddaert 1783 (garden warbler) & 90 & 64 & L (1); Ln (5); MdV (9); U (49) \\
\hline & S. cantillans, Pallas 1764 (subalpine warbler) & 40 & 32 & Ln (21); MdV (11) \\
\hline & S. communis, Latham 1787 (whitethroat) & 8 & 5 & $\mathrm{~L}(5)$ \\
\hline & S. curruca, Linnaeus 1758 (lesser whitethroat) & 1 & 1 & $\operatorname{MdV}(1)$ \\
\hline & S. melanocephala, Gmelin 1789 (sardinian warbler) & 15 & 8 & $\mathrm{~L}(1) ; \mathrm{MdV}(7)$ \\
\hline \multirow[t]{6}{*}{ Turdidae } & Erithacus rubecula, Linnaeus 1758 (robin) & 1 & 1 & $\operatorname{Ln}(1)$ \\
\hline & Luscinia megarhynchos, Brehm 1831 (nightingale) & 4 & 3 & $\mathrm{~L}(1) ; \operatorname{MdV}(1) ; \mathrm{U}(1)$ \\
\hline & $\begin{array}{l}\text { Monticola solitaries, Linnaeus } 1758 \text { (blue rock- } \\
\text { thrush) }\end{array}$ & 1 & 1 & $\operatorname{Ln}(1)$ \\
\hline & Phoenicurus phoenicurus, Linnaeus 1758 (redstart) & 12 & 7 & L (3); Ln (4) \\
\hline & Saxicola rubetra, Linnaeus 1758 (winchat) & 23 & 13 & L (9); U (4) \\
\hline & Turdus philomelos, Brehm 1831 (song thrush) & 1 & 0 & \\
\hline Total & & 349 & $216(61.89 \%)$ & L (33); Ln (33); MdV (39); U (111) \\
\hline
\end{tabular}

$L$ Lampedusa, $L n$ Linosa, $M d V$ Mazara del Vallo, $U$ Ustica 
The results of restriction analysis of 5.8S-ITS region confirmed the subdivision into 12 groups. One strain for each group was identified at species level as follows: Alternaria alternata (Fr.) Keiss1 1912 (strain Uf142-1), Aspergillus tubingensis Mosseray 1934 (strain Uf125-1), Aspergillus niger Tiegh 1867 (strain Uf221-1), Aspergillus ochraceus K. Wilh 1877 (strain Uf76-1), Botrytis cinerea Pers 1794 (strain Uf144-1), Cladosporium cladosporioides (Fresen.) G.A. de Vries 1952 (strain Uf247-2), Fusarium oxysporum Schlecht Emend Snyder AND Hansen 1940 (strain Uf961), Fusarium lateritium Nees 1817 (strain Uf94-2), Fusarium acuminatum Ellis and Everh 1895 (strain Uf1301), Penicillium chrysogenum Thom 1910 (strain Uf147-1), Talaromyces verruculosus Peyronel (strain Uf225-3), and Rhizopus arrhizus var. arrhizus A. Fisch (strain Uf122-1).

Fungal Frequency and Distribution

Table 2 also shows the distribution of the 12 fungal species among birds. The fungal species most frequently isolated from migratory birds were $C$. cladosporioides $(70.90 \%$ ), A. alternata (13.74\%), A. niger (5.39\%), and F. oxysporum $(4.02 \%)$. The highest number of isolates and species were found in the most numerous bird groups. Thus, garden warblers and spotted flycatchers were the richest sources of fungal diversity; on the contrary, golden orioles showed the less diversity in terms of filamentous fungi, since only one isolate was collected from this bird species. All bird species hosting a consistent number of filamentous fungi were characterized by a "trans-saharan" migration. Although $57.34 \%$ of filamentous fungi were isolated from birds with a SFA value comprised between zero and one (Table 3), no significant statistical differences were found among birds with $0-1$ and $2-7$ SFA.

\section{Discussion}

The main aim of the present study was to evaluate the environmental dissemination of filamentous fungi by migrating birds. For this purpose, the cloacae of 349 birds captured soon after landing in four strategic stop-over points during spring and autumnal migration, located in the Mediterranean Sea, were examined. The isolation and identification of these microbial agents gained interest in recent years for safety issues related with birds covering long distances. Hubalek et al. [14] reported a general check-list of human pathogenic filamentous fungi carried by birds, thus, the analysis of filamentous fungi carried by birds and released in small islands like those object of this study is of interest. The isolation of microbial agents from cloacae is particularly important, since it represents the last tract reached by microorganisms after gastric transit.
By means of morphological differentiation 12 fungal groups were collected from cloacae and, for this reason, the primary source of fungal contamination has to be imputable to the food ingested.

By restriction analysis of 5.8S-ITS rRNA region and its sequencing all selected isolates were differentiated into 12 groups in accordance to morphological analysis. On the other hand, for some species such as A. tubingensis, $P$. chrysogenum, and B. cinerea, the microscopic inspection was essential in the recognition of species.

Nowadays, the morphological clustering of the isolates based on dichotomous key analysis [5] associated to the restriction analysis of 5.8S-ITS rRNA region and its sequencing is a reliable technique for the analysis of filamentous fungi till species level [13] showing that a polyphasic procedure is the correct approach to obtain the proper identification of filamentous fungi.

Our results showed that $61.89 \%$ of birds analyzed were positive for the presence of filamentous fungi, showing a higher percentage than that $(10.93 \%)$ reported by Cafarchia et al. [4] who analyzed a similar number of birds (421). These results are probably due to different species of birds captured as well as the sampling sites. To our knowledge, this research represents the first report on the isolation and molecular identification of filamentous fungi carried by living migratory birds at long distances. From this perspective, this is also the first report on filamentous fungi transported by birds in the main migratory stop-over points in the Sicilian area. Since birds were analyzed soon after landing, the contamination of bird cloacae with local filamentous fungi has to be excluded. In a previous study, Francesca et al. [7], by means of persistence tests performed on robins, demonstrated that yeast maybe disseminated approximately $12 \mathrm{~h}$ after ingestion. A similar timing maybe supposed for the other filamentous fungi. This interval is enough to cover a distance within $300-350 \mathrm{~km}$ $[18,19]$ and it is compatible with a no-stop flight commonly performed by birds with low SFA (comprised between 0 and 1) [10]. The body fat is the first energy source dissipated by birds during migration and when SFA reaches a value of 0 or 1 , a stop is necessary [10]. Filamentous fungi isolated in the present study are ubiquitous in several areas and may cause different problems. In particular conditions, only some strains of the fungal species identified play positive roles: $B$. cinerea can positively affect the grape and wine quality (noble rot) [26]; some strains of A. alternata are antagonist of Plasmopara viticola responsible for grapevine diseases [21]; Rhizopus arrhizus var. arrhizus is used in the production of alcoholic beverages in Asia and Africa, since some strains of this species are able to degrade amylase compound of food promoting the alcoholic fermentation [28]. The species with the highest frequency of isolation (C. cladosporioides, 


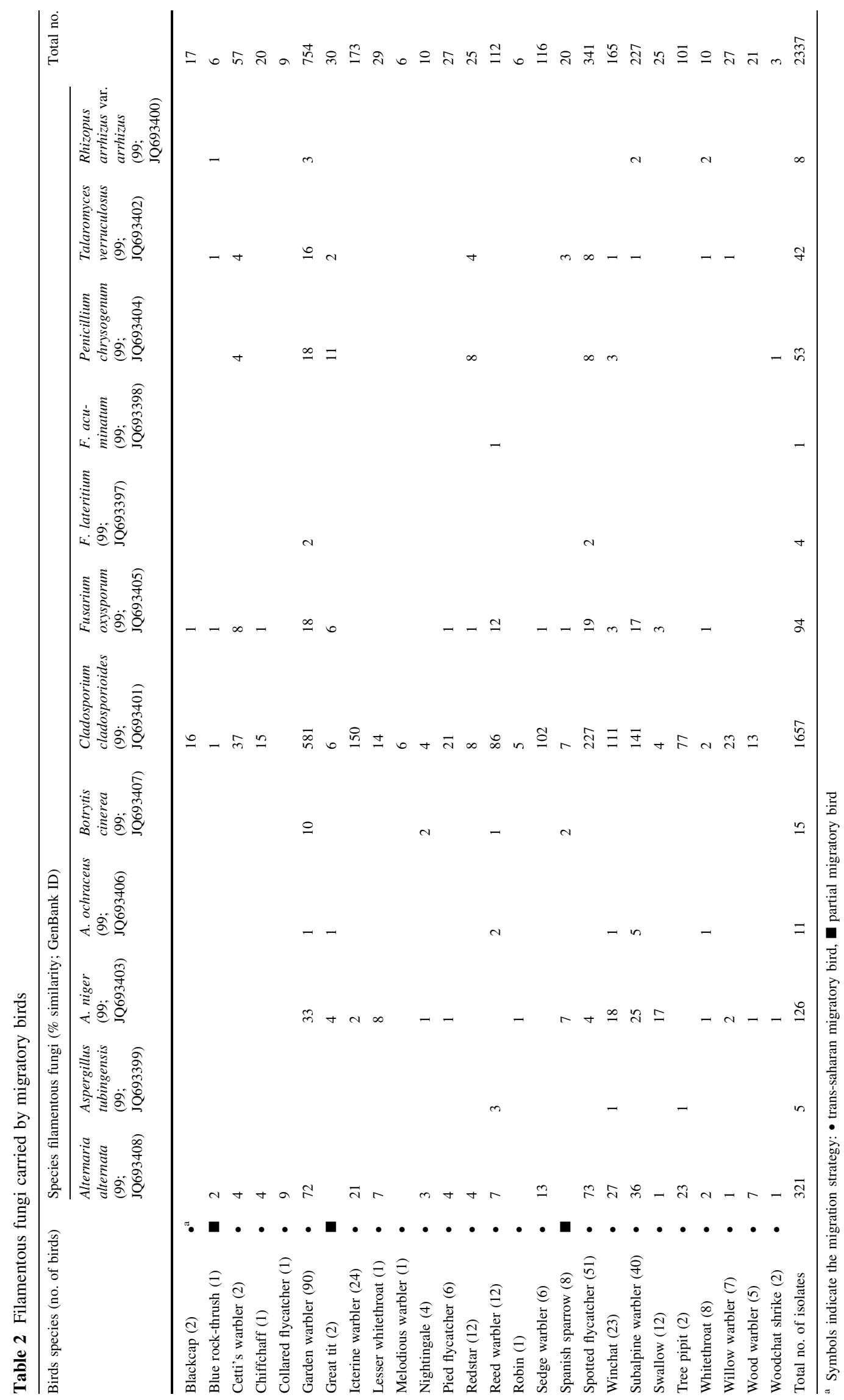


Table 3 Filamentous fungi isolated from birds grouped on the basis of subcutaneous fat amount

\begin{tabular}{|c|c|c|}
\hline \multirow[t]{2}{*}{ Species } & \multicolumn{2}{|l|}{ SFA } \\
\hline & $0-1$ & $2-7$ \\
\hline Total isolates $(n=2,337)$ & $1,340(57.34 \%)$ & $997(42.66 \%)$ \\
\hline $\begin{array}{l}\text { Alternaria alternata } \\
(n=321)\end{array}$ & 171 & 150 \\
\hline $\begin{array}{l}\text { Aspergillus niger } \\
(n=126)\end{array}$ & 77 & 46 \\
\hline $\begin{array}{l}\text { Aspergillus ochraceus } \\
\quad(n=11)\end{array}$ & 7 & 4 \\
\hline $\begin{array}{l}\text { Aspergillus tubingensis } \\
(n=5)\end{array}$ & 3 & 2 \\
\hline $\begin{array}{l}\text { Botrytis cinerea } \\
(n=15)\end{array}$ & 9 & 6 \\
\hline $\begin{array}{l}\text { Cladosporium cladosporioides } \\
(n=1,657)\end{array}$ & 955 & 702 \\
\hline $\begin{array}{l}\text { Fusarium acuminatum } \\
(n=1)\end{array}$ & 0 & 1 \\
\hline $\begin{array}{l}\text { Fusarium lateritium } \\
(n=4)\end{array}$ & 3 & 1 \\
\hline $\begin{array}{l}\text { Fusarium oxysporum } \\
(n=94)\end{array}$ & 63 & 31 \\
\hline $\begin{array}{l}\text { Penicillium chrysogenum } \\
\quad(n=53)\end{array}$ & 29 & 24 \\
\hline $\begin{array}{l}\text { Talaromyces verruculosus } \\
(n=42)\end{array}$ & 23 & 19 \\
\hline $\begin{array}{l}\text { Rhizopus arrhizuz var. arrhizus } \\
(n=8)\end{array}$ & 6 & 2 \\
\hline
\end{tabular}

SFA subcutaneous fat amount

A. alternata as well as members of the genera Aspergillus, Penicillium, and Fusarium) are generally defined as plant pathogens and soil-borne but also allergens for humans and animals [12, 16, 17, 20]. Moreover, most of these species found are well known producers of mycotoxins, common contaminants of foods and feeds [11].

In contrast to other studies $[24,27]$ that showed birds exclusively as vectors of human or animal fungal (yeasts and filamentous fungi) pathogens, most of our isolates represent plant pathogens and/or food contaminants. On the other hand, in accordance to data reported by Tsiodras et al. [27], birds sampled in the present study were found to be carriers of different species of yeast (such as Cryptococcus spp.) as reported in the first part of this study published by Francesca et al. [7].

Migratory birds play an active role in the dissemination of filamentous fungi during their movements from North Africa to Europe and viceversa. The species identified in this study are important because they may represent safety issues for human health. Except for a few species, most of the filamentous fungi identified are responsible for human diseases such as allergies and foodborne intoxication due to their secondary metabolites (mycotoxins) $[11,12,20]$.
These findings are important for the small islands (Lampedusa, Ustica and Linosa) that are not characterized by massive exchanges of people and commodities, except in summer season when tourist activities become relevant or in case of illegal immigration, which may contribute to transport microorganisms; in this context, migratory birds represent the main vectors of fungal biodiversity.

Acknowledgments The authors are grateful to Prof. B. Massa, Dr. D. E. Canale, and Dr. P. Lucido for their help with analysis and interpretation of data. Dr. S. D'Angelo and the staff of Riserva Naturale Integrale Lago Preola and Gorghi Tondi (Mazara del Vallo, TP, Italy) are also thanked for their supervision during bird ringing.

\section{References}

1. Altschul SF, Madden TL, Schaffer AA, Zhang J, Zhang Z, Miller W, Lipman DJ (1997) Grapped BLAST and PSI-BLAST: a new generation of protein database search programs. Nucleic Acids Res 25:3389-3402

2. Barnett HL, Hunter BB (1998) Illustrated genera of imperfect fungi, edition 4. Spiral-bound press

3. Burton NHK, Rehfisch MM, Clark NA, Dodd SG (2006) Impacts of sudden winter habitat loss on the body condition and survival of redshank Tringa tetanus. J Appl Ecol 43:464-473

4. Cafarchia C, Camarda A, Romito D (2006) Occurrence of yeasts in cloacae of migratory birds. Mycopathologia 161:229-234

5. Domsch KH, Gams W, Anderson TH (2007) Compendium of soil fungi, second edition. APS Press, St Paul

6. Elfving K, Olsen B, Bergstrom S, Waldenstrom J, Lundkvist A, Anders S, Mejlon H, Nilsson K (2010) Dissemination of spotted fever rickettsia agents in Europe by migrating birds. PlosOne $5: 1-5$

7. Francesca N, Canale DE, Settanni L, Moschetti G (2012) Dissemination of wine-related yeasts by migratory birds. Environ Microbiol Rep 4:105-112

8. Gardes M, Bruns TD (1993) ITS primers with enhanced specificity for basidiomycetes: application to the identification of mycorrhizae and rusts. Mol Ecol 2:113-118

9. Goddard MR, Anfang N, Tang R, Gardner RC, Jun C (2010) A distinct population of Saccharomyces cerevisiae in New Zealand: evidence for local dispersal by insects and human-aided global dispersal in oak barrels. Environ Microbiol 12:63-73

10. Goymann W, Spina F, Ferri A, Fusani L (2010) Body fat influences departure from stopover sites in migratory birds: evidence from whole island telemetry. Biol Lett 6:478-481

11. Griessler K, Rodrigues I, Handl J, Hofstetter U (2010) Occurrence of mycotoxins in Southern Europe. World Mycotoxin $\mathrm{J}$ 3:301-309

12. Horner WE, Helbling A, Salvaggio JE, Lehrer SB (1995) Fungal allergens. Clin Microbiol Rev 8:161-179

13. Huang WY, Cai YZ, Surveswaran S, Hyde KD, Corke H, Sun M (2009) Molecular phylogenetic identification of endophytic fungi isolated from three Artemisia species. Fungal Divers 36:69-88

14. Hubalek Z (2004) An annotated checklist of pathogenic microorganisms associated with migratory birds. J Wildl Dis 40:639-659

15. Kaiser A (1993) A new multi-category classification of subcutaneous fat deposits of songbirds. J Field Ornithol 64:246-255

16. Kwon JH, Cheon MG, Kim J, Kwack YB (2011) Black rot of kiwifruit caused by Alternaria alternata in Korea. Plant Pathol J 27:298-305 
17. Lòpez-Mendoza MC, Cespo-Sampere A, Martinez-Culebras PV (2009) Identification of Aspergillus tubingensis strains responsible for OTA contamination in grapes and wine based on the acyl transferase domain of a polyketide synthase gene. Int J Food Microbiol 44:2147-2152

18. Moreau RE (1961) Problems of Mediterranean-Saharan migration. Ibis 103a: 373-427

19. Moreau RE (1972) The Palaearctic-African bird migration systems. Academic Press, London

20. Moss MO (2002) Micotoxyn review 1. Aspergillus and penicillium. Mycologist 16:116-119

21. Musetti R, Polizzotto R, Vecchione A, Borselli S, Zulini L, D'Ambrosio M, di Toppi LS, Pertot I (2007) Antifungal activity of diketopiperazines extracted from Alternaria alternata against Plasmopara viticola: an ultrastructural study. Micron 38:643-650

22. Nuttall PA (1997) Hoste-parasite evolution. In: Clayton DH, Moore J (eds) Viruses, bacteria and fungi of birds. University Press, Oxford, pp 271-302

23. O’Donnell K, Cigelnik E, Nirenberg HI (1998) Molecular systematics and phylogeography of the Gibberella fujikuroi species complex. Mycologia 90:465-493
24. Omenn GS (2010) Evolution and public health. In: Ellison PT (ed) Harvard University, Cambridge, pp 1702-1709

25. Svensson L (1992) Identification guide to European passerines. British Trust for Ornithology, Stockholm

26. Tosi E, Fedrizzi B, Azzolini M, Finato F, Simonato B, Zapparoli G (2012) Effects of noble rot on must composition and aroma profile of Amarone wine produced by the traditional grape withering protocol. Food Chem 130:370-385

27. Tsiodras S, Kelesidis T, Kelesidis I, Bauchinger U, Falagas ME (2008) Human infections associated with wild birds. J Infect 56:83-98

28. Vu NT, Le TM, Duong AT (2008) Microbial diversity of traditional Vietnamese alcohol fermentation starters (banh men) as determined by PCR-mediated DGGE. Int J Food Microbiol 128:268-273

29. White TJ, Bruns T, Lee S, Taylor J (1990) PCR protocols: a guide to methods and applications. In: Innis MA, Gelfand DH, Sninsky JJ, White TJ (eds) Amplification and direct sequencing of fungal ribosomal RNA genes for phylogenetics. Academic Press, San Diego, pp 315-322 